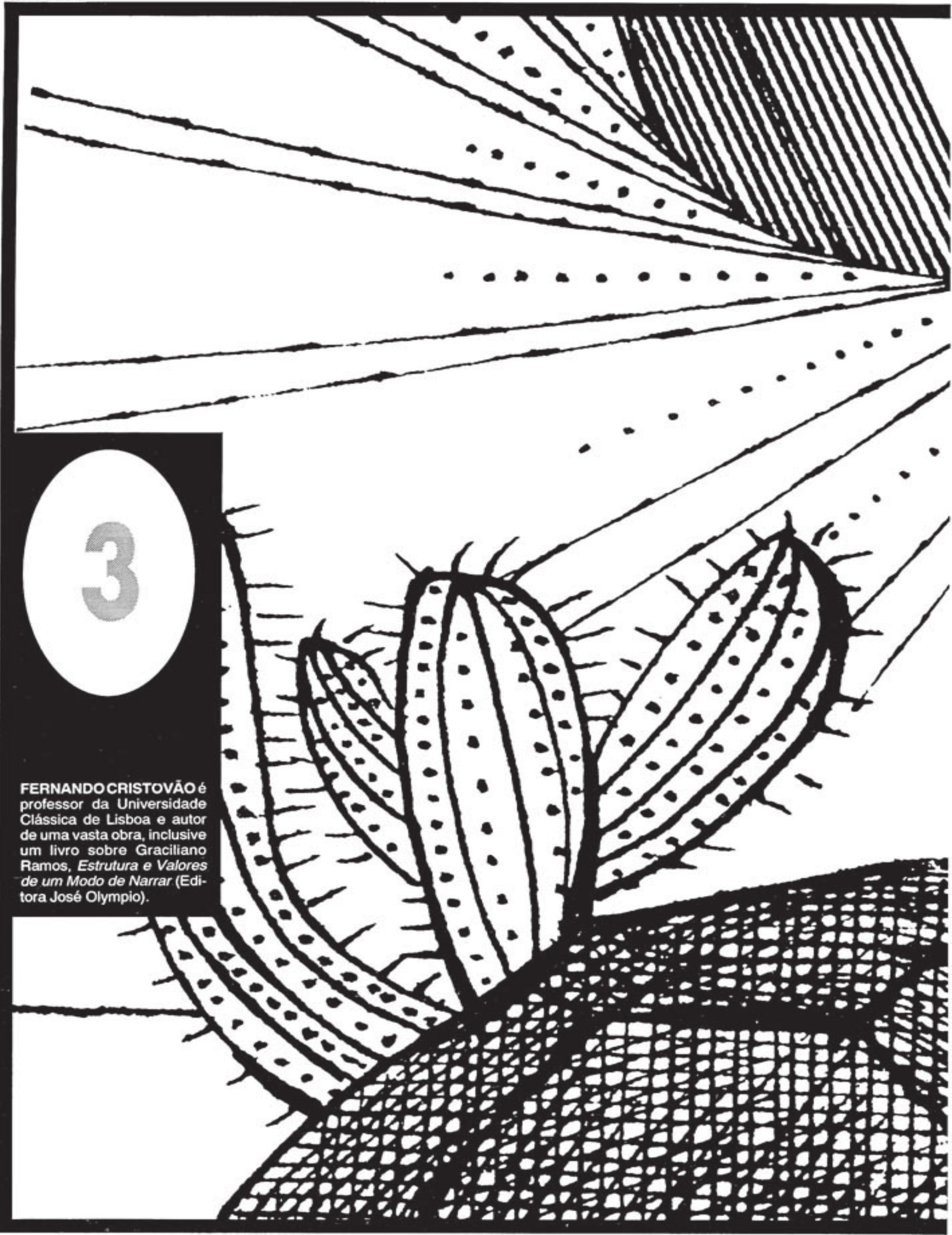




\section{A transfiguração da realidade sertaneja e a sua passagem a mito (A Divina Comédia do Sertão)}

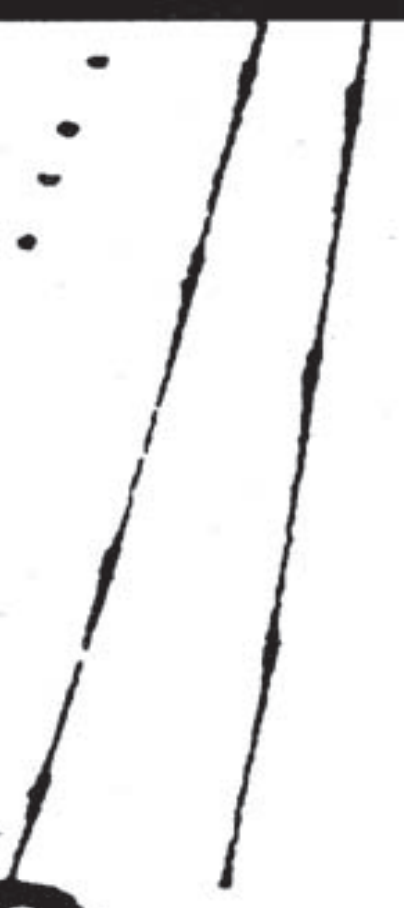

-

-

$-$

$\cdot$ mantismo, nasce da confluência de três vetores que em muito condicionarão o seu entendimento: o das descriçōes da terra brasílica versus terra lusitana, o do mundo rural versus mundo urbano, o do tempo passado versus tempo presente.

Podeafirmar-se, por isso, que desde muitocedo a realidade sertaneja se afirmou como área de confrontos, como espaço privilegiado de interrogações equestionamentos, comosubstância de mitologias.

Por outras palavras, sertão é lugar que, simultaneamente, se afirma e se nega, é tempo sobretudo de outros tempos, é reino do fantástico e do mítico.

Com efeito, nele irrompem manifestações e fatos estranhos sobressaindo ora da força telúrica da terra, ora da ausência da água, ora do furor dionisíaco do fogo, ora de epifanias 
estranhas do "ar", doindeterminado, entendido à maneira das teorias dos primeiros filósofos gregos. Por isso se ultrapassou a fase descritiva do sertão florido e inocente, passando-se depois do Modernismo a encarar a realidade como vasto espaço atravessado por lendas e encruzilhadas onde os mais diversificados $\mathrm{e}$ inesperados encontros podem acontecer.

Há, pois, múltiplas e complementares leituras do sertão iniciadas praticamente no Romantismo, e que não mais cessaram até os dias de hoje.

Os primeiros a fazê-las foram os poetas, desde a segunda metade do século XIX: Álvares de Azevedo, Casimiro de Abreu, Junqueira Freire, Castro Alves, em especial. Celebram a natureza florida e os amores que eramoseu prolongamentonatural. Mas vão ser, sobretudo, os romancistas quem mais se ocuparão do sertāo. Nesta primeira fase da sua revelação, duas datas -1869 e 1875 - avultam como fundamentais.

Em 1869 publicou Bernardo Guimarães OErmitāo de Muquém, opondo à descrição das florestas e praias dos índios a descrição dos largos campos sertanejos e do homem que os habita, descriçōes estas que a outra obra, O Indio Afonso (1873), confirmaria. Em 1875 publicou Alencar $O$ Sertanejo, a obra-prima e de síntese do sertão romântico e tranqüilo, onde a paz e a felicidade se dão as mãos para que tanto o senhor como o servo se sintam felizes.

Logo no ano seguinte, Taunay quebraria esse encanto paradisíaco numa obra perturbada e perturbadora -Inocência (1876)operando a mudança para uma segunda fase em que a tensão dramática substituiria a quietude contemplativa. Dramaticidade que se adensava à medida que Taunay ia escrevendo sobre as convulsōes da guerra: $\mathrm{Ce}$ nas de Viagem, Diário do Exército, A Retirada da Laguna, etc.

A força telúrica que emana de Inocência e o tônus musical que soube imprimirlhe em certos momentos em muito contribuíram para a predileçāo do público e para a voga do tema, até porque soube lançar mão de um processo editorial de sucesso garantido - a publicação em folhetim.

Assim se passou de um entendimento predominantemente romântico dos sertōes para uma visão mais situada, de teor realista, que haviade ser aprofundada por Franklin Távora em 1876, em $O$ Cabeleira, e por Manuel de Oliveira Paiva ao divulgar o seu Dona Guidinha do Poço (postumamente publicadoem 1952), uma obra extraordinária em todos os sentidos, a que a crítica e a historiografia literária não prestaram ainda a devida justiça.

A publicação de Os Sertōes, em 1902, ae Euclides da Cunha, levaria aoponto mais alto a fase da problematização realista-naturalista, com todas as qualidades e defeitos próprios da escola. Problematizaçãoestaque se prolongará com especial felicidade nos romances de Graciliano Ramos e de Jorge Amado.

Outras obras contribuíram para consolidar a temática sertaneja como, por exemplo, OSertão (1896), de Coelho Neto, ou o PeloSertão(1898), de Afonso Arinos, mas sem abrirem novas perspectivas, antes atualizando e desenvolvendo esboços e tipos criados pelo teatro de Martins Pena ( $O J u i z$ de Paz da Roça, Festa da Roça, Um Sertanejo na Corte) e dos seus seguidores que, nos costumes sertanejos, encontraram abundante matéria para comédias. A primeira porque se limitou a exercícios literários de um romantismo exacerbado que em Portugal apelidaríamos de ultra-romântico, a segunda por se preocupar mais com a cor local, a construção de tipos, a evocaçăo do passado, a reconstituição da linguagem matuta do que com uma simbolizaçăo global. O seu mérito, que não é pequeno, está sobretudo no grande impulso dado à literatura regionalista, quaisquer que sejam os juízos de valor que se possam fazer sobre a autenticidade das suas descriçōes e retratos. E, na esteira já aberta, obras como Contos do Sertāo (1912) de Viriato Correia, Tropas e Boiadas (1917) de Hugo Carvalho Ramos, Os Caboclos (1920) de Valdomiro da Silveira, Samambaia (1934) de Roquete Pinto e outras.

Uma terceira fase, caracterizada pela ultrapassagem da problematização social dominante e pela proposta de uma visão diferente da realidade de teor mítico, é inaugurada por Guimarães Rosa no Pós-Modernismo, em 1946, com Sagarana, e solidamente estruturada principalmente em GrandeSertão: Veredas, de 1956. Veredas estas que foram muito freqüentadas também por Ariano Suassuna que, em 1971, nos deu, em A Pedra do Reino, o que José Lins do Rêgo já nos fizera adivinhar em 1938 e 1953 em Pedra Bonita e Cangaceiros: que o sertãoé também um reino encantado.

Mas, por mais diversificadas que sejam estas três formas de tratamento, a realidade 
de base que lhes empresta a legitimidade de transfiguraçōes-simbolizaçōes do referente é uma só, e importa defini-la desde já: há um só sertão, concretizado em muitos sertões. Porque o sertão, tal como outras referências geográficas, tem, nos escritos de criação literária, uma amplitude que não se compadece com os dados da geografia nem com os da antropologia cultural.Édiferente e outro, tanto na quantidade como na qualidade, porque projeta o próprio homem através da simbolização estética.

Contudo, uma relaçăo estreita o liga a essa realidade nos dados essenciais. Dir-seia que o fingimento poético, não querendo ser tão arbitrário como o signo lingüístico, guarda sempre as dimensões de uma representação proporcionada ao real: nemé convencional nem servil, antes reúne a solidariedade à independência, tal como as variações musicais ilustrando um tema.

O sertão celebrado pela literatura toma como ponto de partida os dados objetivos da região mediterrânica pastoril (1) onde a criação de gado estabilizou as populações adaptadas ao meio. Diversifica-se em subregiốes onde o criatório constituiu, sob o ponto de vista econômico da forma de ocupação humana, o elemento mais caracterizador. Um mesmo sertão se reconhece, por isso, no Ceará, no Rio Grande do Norte, na Paraiba, em Pernambuco, em Sergipe, nas Alagoas, na Bahia ou em Minas Gerais. A ponto de o devermos entender, acima de tudo, como uma região do interior, de criação de gado, desértica, mais ou menos estacionada num passado que se recorda como santuário ou reserva das tradiçốes ancestrais, repositório venerado da linguagem e costumes antigos.

Foi, pois, a partir destes dados, que a ficçāo literária teceu o bordado da sua tradição, e de um modo tal que, a partir da proposta ficcional de Guimarães Rosa lançando a idéia da travessia e encarecendo a importância das veredas para oentendimento da realidade sertaneja, nos atrevemos a decifrar a literatura sobre osertāo comouma divina comédia - a do homo viator.

Foi, pois, a partir destes dados que a ficção literária teceu o bordado da sua tradição. Tradição essa que por insistir em determinados aspectos nos sugere que os articulemos de um modo valorativo global.

Com efeito, os autores que nas três fases anteriormente referidas descrevem, questionam ou mitificam o sertão comparam-no, freqüentemente, ao paraíso, ao inferno ou ao purgatório, insinuando que, entre as muitas leituras possíveis, uma que vá buscar à visão de Dante na Divina Comédia sugestőes para um melhor entendimento, talvez, melhorque outras, possadar-nosuma idéia de totalidade capaz de explicar as contradiçōes e mistérios do espaço sertanejo.

Ainda que separadas por práticas e conceitos de humanismo tão diferentes como os medievais e os contemporâneos, as sugestōes desse poema contidas nas suas linhas estruturais podem dizer-nos muito sobre o sertão brasileiro. Como afirma ArianoSuassuna, pela boca sábia do Quaderna da Pedra do Reino, resumindo todos os escritos sobre o sertão, "na verdade a face do sertāo é tripla: o Inferno, o Purgatório e o Paraíso" (2).

Enãodeve este entendimento dosertão, sobretudo na sua faceta eufórica de paraíso, ser confundido com o que, tradicionalmente, se faz em relação a outras regiōes do Brasil como a Amazônia. É que, nessa vastidâo de águas e florestas digna das gravuras de Gustavo Doré, a perspectiva adotada é a doÉden vivendo ainda os primeiros dias da criação ou sendo devastado pelos homens (por exemplo, em Raimundo Morais, Raul Bopp e Alberto Rangel), em contraste com esta do sertão inquieto nos dramas dos seus itinerários.

\section{O SERTÃO COMO PARAÍSO}

Diferentemente do itinerário percorridoporDante que, na companhia de Virgilio, começou por visitar o inferno, os viajantes literários do sertâo começaram pelo paraíso.

A beleza da terra transfigurada pelas chuvas impôs-se desde os românticos como impressãoprimeira e iniciática. Até mesmo a Euclides da Cunha que, antes de descrever e escalpelizar os acontecimentos dramáticos de Canudos, se extasiou diante dela. Descrevendo a transformaçāo prodigiosa operadapelos aguaceirosdiluvianos ele diz:

"ao tornar da travessia o viajante, pasmo, não vê mais o deserto. Sobre o solo que as amarilis atapetam, ressurge triunfantemente a flora tropical.

É uma mutação de apoteose.

Os mulungus rotundos, à beira das cacimbas cheias, estadeiam a púrpura das
1 Manuel Diégues Júnior, Regídes Cuturais do Brasil, Rio, INEP, 1960, pp. 160-1.

2 Aviano Suessuna, A Pedra do Reino, 24 ed., Alo, José Olimpio, 1972, p. 3. 
largas flores vermelhas, sem esperar pelas folhas; as caraibas e baraúnas altas refrondescem à margem dos ribeiröes refertos; ramalham ressoantes, os mariseiros esgalhados à passagem das viraçōes suaves; assomam, vivazes, amortecendoas truncaduras dasquebradas, as guixabeiras de folhas pequeninas e frutos que lembram contas de orix; mais virentes os icoseiros pelas várzeas, sob o ondular festivo das copas dos ouricuris: ondeiam, móveis, avivando a paisagem, acamando-se nos plainos, arredondado as encostas, as moitas floridas do alecrim dos tabuleiros, de caules finos e flexíveis; as umburanas perfumam os ares, filtrando-os nas frondes enfolhadas e - dominando a revivescência geral - não já pela altura senão pelo gracioso do porte, os umbuzeiros alevantam dous metros sobre o chão, irradiantes em círculo, os galhos numerosos".

E, rematando:

"E o sertão é um paraíso" (3).

E como paraíso esses viajantes literários o descrevem, aliando as características clássicas dos topica relativos à natureza estudadas por Ernest Curtius às modernas sugeridas pela sensibilidade romântica ou simbolista. Osertãoé, assim, umnovoÉden.

A descrição da paisagem desse novo Éden, ainda que em vias de se perder, é feita não já sob os traços do pequeno bosque clássico acolhedor e confiante, onde abundavam as árvores perfumadas misturando seus odores, mas como locus amoemus adaptadobrasilicamente aovastoespaçodos gerais, conservando, ainda que em proporções diversas, os elementos básicos da sua caracterização: o prado, algumas árvores, uma fonte ou ribeiro, o canto dos pássaros, a profusão das flores, a brisa ou o vento.

Nesse contexto, se descrevem amores tẩo campestres e simples, como intensos e fatais.

Álvares de Azevedo em "A Cantiga do Sertanejo" (4) canta em estrofes repassadas de sentimento os seus amores que, obrigatoriamente, se associam à noite e ao luar, sem esquecer as flores e a harmonia da natureza: "Ah! se viesses, donzela/verias que a vida é bela/No silêncio do sertão". Mas a esse silêncio Fagundes Varela preferia, no longo poema "A Roça” (5), obulício da convivência onde não faltavam as violas, as modinhas, os lundus, o cigarro, o café, naquele paraíso de largos horizontes onde saltam os novilhos e relincham os fogosos corcéis. Elamentava que essa paz, harmonia e virtude estivessem a acabar, e que ele próprio as tivesse abandonado, pois se o não fizesse nāo se teria coberto de lama e escárnio. Completa esse lamento, contando, num poema longo, "Mimosa - Poema da Rosa" (6), que a virtude dos sertōes já nãoć a de outros tempos, e os amores já são de ingratidão e de cálculo.

Louvando a Bela dos seus amores, Junqueira Freire em "O Menestrel do Sertão" (7) é mais comedido no coro dos louvores, chamando a atençăo para a existência de outros aspectos, menos positivos, por isso esclarece: "Canto tudo quanto vejo/No sertäo da minha terra; canto o belo, canto o feio/canto a paze cantoa guerra;/canto tudo o que me inspira;/que me encanta, ou o que me aterra".

E também o poeta condoreiro Castro Alves nảo faltou a essa celebração de amores do paraíso no poema "América" (8), emprestando-lhe o tom pungente da música: "Passa o vento das campinas,/leva a cançāo do tropeiro. Está deserto o mundo inteiro,/que viu a minha senhora/Dona do meu coração?/Chora, chora na viola/violeiro do sertão".

Esta tradiçãopoética iria conhecer, meio século depois, um continuador que a levaria à saturação, Catulo da Paixão Cearense, o mais celebrado membro da "trindade caipira" que, especialmente em serestas aoluar e em obras como Meu Sertāo, Sertäo em Flor e Alma do Sertão, haveria de popularizar o tema no Brasil e em Portugal.

Este relacionamento estreito entre o amor e o sertão é tão natural que continuará mesmo fora deste tópico ou de qualquer outro. A prová-lo está o livro de contos $O s$ Caboclos (9) de Valdomiro Silveira, obra muito importante para o estabelecimento do regionalismo, onde quase todas as narrativas têm as relaçōes amorosas como tema, relações ora bem-sucedidas ora infaustas ("Cena de Amor", "Camunhengue", "Salvação", "Os Curiangos").

Contudo, os mais eficazes construtores do tópico do sertão florido foram os prosadores Bernardo Guimarães, em O Ermitão de Muquém (1869), e José de Alencar, em O Sertanejo (1875). Eles contribuíram, decisivamente, para o estabelecimento de uma tipologia do sertão, quer aproveitan- 
do-se dos modelos retóricos tradicionais, oriundos do topica da cultura medieval latina veiculadopela cultura portuguesa, quer recriando-os e ampliando-os ao ambiente dos trópicos, e dentro de uma perspectiva brasileira muito própria, a do chamado regionalismo.

Em $O$ Ermitão de Muquém, o cenário indianista completa-se ou prolonga-se no cenário sertanejo com a mesma naturalidade com que a história dos amores de Gonçalo e Maroca passa dos vastos campos de Goiás para as florestas habitadas pelos índios chavantes, contrapondo ao guerreiro altivo destas o vaqueiro corajoso e indômito daqueles.

Mas foi sobretudo em $O$ Sertanejo, de Alencar, obra-chave nesta construçāo literária, que o sertão se revelou em todo o seu esplendor paradisíaco. A fazenda Oitícia tornou-se o símbolo do lugar edênico dos trópicos onde, no quadro tradicionalista da família do capitão-mor, seus agregados e servos, florescem os amores de D. Flor e Arnaldo. Tudo ali é formosura, pureza de intençōes, susto e rubores de gente ingênua e simples. Abundam os bons sentimentos, a linguagem prudente e elegante, um verdadeiro campo de flores, pássaros e animais:

"Nas abas da serra onde as árvores tinham conservado a verdura sentia-se passar pela floresta um estremecimento de prazer. A brisa da manhā enredandose pela ramagem rociada não mais arranca os murmúrios plangentes da mata crestada. Agora o crepitar das folhas é doce e argentino, como um harpejo sorridente.

Nãoeram somente as matas, os silvaçais e as várzeas que se arreavam com as primeiras galas do inverno. Oespaçoaté ali mudo e ermo na limpidez de seu azul diáfano, começou por igual a povoar-se de pássaros, que durante a seca se refugiaram nas serras e emigraram para climas amenos.

Já se ouviram granizar as maracanãs entre os leques sussurrandoda carnaúba a repercurtirem os gritos compassados do cancã saltando pela relva. O primeiro casal de marrecas, naquele chegado das margens do Paranaguá, a centenas de léguas, banhava-se nas águas de um alagado produzido pela chuva" (10).

E esta imagem do sertão, digna das gravuras de Gustavo Doré, não se confina aos textos românticos, persiste no Realismo, embora misturada com outros menos repousantes e agradáveis, e vem até os nossos dias.

Taunay prolonga-a recuperando, de algum modo, o motivo clássico da enumeração das espécies arbóreas que prestigiam o cenário, mencionando, como outros, o gravatá, os coqueiros, o buriti e várias espécies de palmeiras, os ipês, os juazeiros, os umbuzeiros, um nunca mais acabar de espécies "a ciciar a modo de harpas eólicas".

Envolvendo estas belezas de fauna e flora, um ambiente de magia e mistério é acrescentado, o do luar misturando-se com a música e convidando ao canto, à dança ou à intimidade na descrição de Hugo de Carvalho Ramos em Tropas e Boiadas:

"No terreiro, à míngua de azeite, morriam as lamparinas dos cruzeiros, e o miraculoso luar do sertão, tão límpido e sugestivo naquelas terras, entrava por toda a parte, espancando geramubas, devassando meandros, coado aqui pela galhada das gameleiras, alastrando-se acolá, sem mancha esem obstáculopela lhanhura plana dos chapadões" (11).

Quanto à música, e contraditoriamente à tradução clássica que a ouve de dia, executada por pastores em suas avenas e flautas, é, no sertāo noturno, arrancada plangentemente de violas e violōes como bem o exemplificou Catuloe descreveu Afonso Arinos no Pelo Sertâo:
"A solidão foi-se enchendo de melodi- as, foi-se povoando de sons dessa músi- ca espontânea e simples tão bárbara e tão livre de regras onde a alma sertaneja ou geme, campeia vitoriosa ou ruge trai- çoeira - irmā gêmea das feras, dos ron- $\cos$ da cachoeira, o murmulho suave do arroio, do gorjeio delicado das aves e do tétrico fragor das tormentas. O idílio ou a luta, o romance ou a tragédia viveram no relevo extraordinário desses versos mutilados, dessa linguagem brutesca da tropeirada" (12).

No sertão-paraíso, vive-se uma nova Idade de Ouro.

Outra forma com que tem sido olhado o sertão é a de situá-lo fora do nosso tempo, numa época sem carênciasou conflitosnem com Deus nem com os homens, descrevendo-o em função das vertentes clássicas do

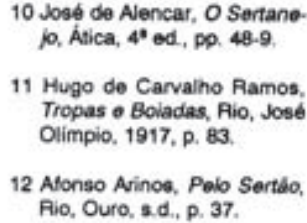


tópico, na análise de Bonéjam-Bomtemps (13): a paz, a abundância, a justiça, devidamente adaptadas à circunstância brasileira.

Os textos românticos limitam-se a contemplar essa idade dourada, os posteriores recordam-na e apontam o que resta desses bons velhos tempos.

A paz é a da vida familiar calma, tranqüila, observante de um estatuto familiar e social estável e incontestado, como na rotina da fazenda Oitícia de $O$ Sertanejo. As perturbaçốes ali ocorridas em certos momentos mais não servem que para confirmar a regra do signo bom, belo e verdadeiro que governava aquele oásis.

Nessa época os amores eram ingênuos, tanto na sua versāo platônica (Arnaldo e D. Flor) como na sua versão fatal (Quirino e Inocência, Cabeleira e Luísa). Igualmente serenos e puros eram os divertimentos populares das argolinhas, das prendas, das folias do divino, dos festejos de S. João, das cavalhadas e vaquejadas como se encontram abundantemente descritos em $O$ Sertanejo, Dona Guidinha do Poço, Tropase Boiadas. A religião observava as tradições antigas trazidas pelos portugueses de antanho nas rezas de novenas e terços, nas festas da semana santa, na devoção à Virgem aqui invocada como a Senhora da Abadia.

Quanto ao motivo da abundância, ele não é, obviamente, muito expressivo no sertão na sua forma literal, antes apanágio da exuberância das casas-grandes da zona da mata.

Mas a ele se assemelha muito na versão aculturada da hospitalidade franca, genero$\mathrm{sa}$, cheia de calor humano encontrada nas fazendas ou, mesmo, nos pousos.

O motivo da justiça conserva, no sertão, a idéia clássica e virgiliana de que é entre os rústicos do campo que a retidão de caráter e a piedade melhor se conservam, e lembra a história antiga de que a deusa Justiça antes de retirar-se para o Olimpo foi entre eles que deixou as suas últimas pegadas. Daí o ambiente de temor a Deus, do culto da honra e da palavra dada, do amor filial e conjugal, da pureza, da austeridade nos costumes conforme o registro de José de Alencar em $O$ Sertanejo:

Marie Joseph Bonéjam. Bomtemps, "Age d'Or", in Dictionnaire des Mythes Littiraires, Paris. Roches. 1988.

14 Euclides da Curha, "Nota Preiminar, in Os Sertoes, op. cit. p. 1.
"Nem é de admirar se encontrasse na morada dos nossos antepassados essa seme-lhança com os conventos quando o teor da vida humana tanto se parecia com a regra monástica, e as mulheres tinham noseioda família o mesmo recato das freiras".

E Euclides da Cunha, como outros, lamentava que esse clima de civilização fosse desaparecendo, apressando-se, por isso, a fixar para a história alguns aspectos observados por ocasião da campanha de Canudos: "os traços atuais mais expressivos das sub-raças sertanejas do Brasil”, porque eles estāo "destinados a próximo desaparecimento ante as exigências crescentes da civilização e a concorrência material intensiva das correntes migratórias que começam a invadir profundamente a nossa terra" (14).

Nesta ótica de evocação de um tempo passado, de um paraíso perdido, em que tudo era mais perfeito, mais justo e mais belo e que, por isso, é recordado, deve situar-se uma das características mais marcantes da literatura regionalista, em geral, e do sertāo em particular: ouso que nela se faz da linguagem simples do povo, linguagem pretensamente mais pura e vernácula porque mais próxima das suas origens lusitanas. Além disso, porque tendo o poder de evocar tempos passados, pode emprestar autenticidade e tipicismo aos relatos e, simultaneamente, demarcar-se da linguagem, costumes e comportamentos das cidades, contribuindo para uma maior homogeneidade do relato. Por isso, críticos como Gladstone Chaves de Melo consideram que se se quisesse restringir muito o conceito de regionalismo, era ao uso da linguagempopular, tanto novocabulário como na sintaxe, que se devia circunscrever, embora tal năo se recomende pelas ambigüidades e indefiniçōes que acarreta.

Um tal emprego da linguagem popular, particularmente em Guimarães Rosa, tem ainda a vantagem, evidenciada por Heron de Alencar, de recriar poeticamente, com sucesso, a estrutura mental do sertanejoque ela reflete.

Momentos privilegiados desse uso são, por exemplo, Pelo Sertão, Os Caboclos, Veranico de Janeiro, os poemas de Catulo e, sobretudo, a obra-prima Grande Sertāo: Veredas. Os livros de contos, por estarem mais próximos da realidade, a poesia de Catulo por tê-la popularizado. E pouco interessa para o caso que a poesia de Catulo seja postiça e artificial, porque a criação literária é mais território da verossimilhança que da realidade. Quanto à obra de Rosa, a autenticidade vem-lhe da fusão genial da linguagem antiga com os mais avançados 
processos de criação literária e da erudição.

\section{O SERTĀO COMO INFERNO}

Mas, subjacente a esta evocação do passado havido sempre como melhor que o presente, há um sentimento que se vai avolumando à medida que nos aproximamos do período realista: o de que esse é um paraíso perdido de que só restam alguns oásis e boas lembranças. Soluçāo esta que coincide com a passagem da explicação teológica ou, simplesmente, religiosa própria dos românticos, para a explicação julgada científica pelos homens do positivismo realista.

Cada vez parece mais claroque o sertãoparaíso é mais uma dádiva da natureza que uma construção do homem, sobretudo a partir da verificação de que o homem podia contrariar os efeitos maléficos das secas e da miséria, masque nãoo faz por apatia, por esperar impossíveis milagres, por incorreta organização social que só favorece os poderosos entretidos em futilidades e mesquinhos jogos de poder e riqueza.

Na visão edênica e idílica do sertāo, a seca pouco mais era que forma de valorizaçăo da natureza na fase posterior às chuvas, de ocasiäo providencial para se evidenciar o poder protetor e salvador dos senhores $\mathrm{e}$ de exaltaçäo comovida das caridades das sinhás. Mas, à medida que se torna claro que os poderosos não são modelos de virtude, que obem nem sempre é premiado nem o mal castigado, um novo olhar vai observandoo sertāo causticado e miserável, e um novo entendimento se desenrola. Afinal, o sertāo é mais inferno que paraíso, e talvez esteja mais sob o signo da desordem, da violência e do demônio, que da harmonia, da paz e de Deus.

Perante as contradições encontradas, Taunaye Franklin Távorahesitamentre uma explicaçāo-solução moralista, e uma explicaçăo-solução social e política.

Euclides, José Américo de Almeida, Graciliano e Jorge Amado já não têm hesitaçōes. Para eles, ainda que sob formas diversas, os homens e não Deus é que são os responsáveis, e, como diria Sartre, "o inferno são os outros", fato que é preciso transformar, sem oque osertāoserá sempre palco do inferno da violência social.

Noutra perspectiva, e contrariamente ao sertão-paraíso que era estático por se movimentarem pouco as pessoas e se ter parado no tempo, o sertão-inferno é, sobretudo, espaço percorrido permanentemente por muita espécie de viandantes, de que se salientam, pelo seu poder de intervenção cruenta, os cangaceiros, as volantes, os beatos ateando ódios e semeando a discórdia.

O sertảo é inferno, antes de mais nada, pelo destempero da natureza abrasada por um sol de fogo e pelas chamas dos incêndios, pelo castigo das secas expulsando os retirantes e seus animais morrendo na fuga e degradando-se em atos de antropofagia, para sobreviver ou adiar a morte.

É inferno pelo desespero dos condenados que nele deambulam como em círculo fechado (retirantes, cangaceiros, volantes, beatos) pretendendolibertar-se pela violência.Violência dos retirantes projetados para fora das suas terras, violência dos cangaceiros praticando uma vingança que não poupa inocentes, violência das volantes que a pretexto de restabelecerem a ordem semeavam novos ódios e desordens, violência dos beatos incendiando o sertäo com promessas utópicas que conduziram a comportamentos desvairados. Verdadeiramente exponenciais dessa violência foram os episódios da Pedra Bonita, em 1837, romanceada por José Lins do Rego em Pedra Bonita, e pela campanha de Canudos iniciada em 1896, descrita por Euclides em $O s$ Sertōes.

Por isso o fatalismo sertanejo se instalou como expressão de falta de toda e qualquer esperança. Dirá a mãe do Domício de Pedra Bonita:

"sertanejo é assim mesmo: vem santo, vem cangaceiro, vem volante (...) vida de sertanejo é esta que tu está vendo. Quando não é cangaceiro é a volante fazendo esta desgraça que tu está vendo" (15).

É esse mesmo fatalismo sertanejo que mais dificulta os diversos tipos de solução que foram sendo tentados: o do progresso técnico do desenvolvimento preconizado pelo Lúcio da Bagaceira, o da fé dos beatos esperando um milagre, como do beato Sebastiāo de Pedra Bonita, o da sublevaçāo dos cangaceiros como Aparício, do mesmo romance, o da revoluçãoe da luta de classes preconizada pelo Juvêncio de Seara Vermelha.

A todas o sertāo parece encarcerar na sua imensa fornalha de fogo onde se agitam, como autênticos condenados, esses anti-heróis por excelência, os cangaceiros. 
Excluídos pela justiça, lançados para a margem do convívio social, perseguidos pelas volantes, sem esperança de perdão ou salvação, sabem que não têm futuroe erram pelo sertão como em círculos fechados destruindo até serem destruídos.

Cabeleira é o seu símbolo, e dele nos deixou Franklin Távora um retrato pintado à maneira realista:

\section{"segundo as tradições mais correntes e autorizadas o Cabeleira trouxe do seio materno um natural brando e um cora- ção benévolo. A depravação que tão funesta lhe foi depois, operou-se dia por dia, durante os primeiros anos, sob a ação ora lenta ora violenta do poder paterno, o qual, em lugar de desenvolver e forta- lecer os seus belos pendores, desenca- minhou o menino, como veremos, e o reduziu a uma máquina de cometer cri- mes" (16).}

Ao lado deles e em círculos que, freqüentemente, os interceptam (apoiando e abençoando não poucas vezes os cangaceiros), também os beatos vivem um destinode exclusāoe danaçāo, interiorizandoou transferindo para a comunidade a maldiçäo de que estãopossessos. Excluídos pela Igreja, vivem o paradoxo de levar até as últimas conseqüências as pregaçōes apocalípticas que nela faziam os pregadores das santas missōes e os propagadores devotos de obras de inspiraçăo jansenista, como a famosa "Missão Abreviada", que não faltava nas magras bibliotecas dos presbitérios sertanejos. Anunciando o fim domundoe ojuízo final iminente, descrevem as chamas do inferno em fixação psicológica criadora de vertigens coletivas e de psicoses de pessimismo e desespero.

Alucinados como Antônio Conselheiro ou o Santo da Pedra Bonita caminham com os seus seguidores para a destruiçăo.

Tem, por isso, grandessemelhançascom o retratopintado por Taunay oque Euclides da Cunha esboçou do Conselheiro:

"O asceta despontava, inteiriço, da rudeza disciplinar de quinze anos de penitência. Requintara nessa aprendizagem de martírios, que tanto preconizam os velhos luminares da Igreja. Vinha do tirocínio brutal da fome, da sede, das fadigas, das angústias recalcadas e das misérias fundas. Não tinha dores desconhecidas. A epiderme seca rugava-se- lhe como uma couraça amolgada e rota sobre a carne morta" (17).

Nãoadmira, pois, que nosertão as crianças desde muito cedo aprendam a palavra inferno muito antes das outras. Éocaso, por exemplo, dofilhomais velhodoFabiano de Vidas Secas que, tendo-a ouvido de Sinhá Terta, a repetia, inocentemente, sem reparar que a dura vida de cada dia a explicava de maneira dura e exaustiva.

O mesmo Fabiano era deste modo que interpelava esse menino que, exausto, se sentara no chão a chorar: "Anda, condenado do diabo" (18).

\section{O SERTÃO COMO PURGATÓRIO}

Na Divina Comédia o Purgatório é uma montanha difícil e escarpada que se levanta do Oceano do Ser e dá acesso ao cume celestial. É o lugar da grande passagem da ignorância à sabedoria e à salvação. Reino da liberdade, nele cada homem prepara o seu futuro.

O sertão-purgatório é o da passagem do sertāo-infernoao sertão-paraíso que, depois de perdido novamente, se demanda. Mas, diferentemente do purgatório de Dante, o purgatório sertanejo é o da imensidão dos gerais onde se realiza uma travessia de purificação na busca de uma sabedoria transfiguradora da vida.

Aliás, entre as palavras-chaves definidoras dosertão há sobretudoduasque avultam pela frequência do seu emprego e pela riqueza de significaçōes: viajante (nāo se chama Pelo Sertâo uma das principais obras desta temática?) e deserto. E estas palavras e conceitos subsumem o entendimento do sertão como purgatório, porque simbolizam adequadamente a condição humana como de homo viator.

E tanto num como noutro purgatório, é o exercício da liberdade e a dramaticidade da escolha que dāo sentido à travessia.

Convém lembrar que o tema do deserto está intimamente ligado a uma tradição cultural milenar que tem inspirado tanto a literatura ascética como a política, porque ele é o lugar onde o sagrado e o profano se encontram e defrontam, e onde a austeridade do meio aliada à ausência de coações psicológicas do grupo permitem uma reflexão serena e uma decisão amadurecida. Deserto é lugar árido, mais freqüentado pelos animais selvagens que pelos homens, 
povoado de espíritos, demônios, assombrações. Lugar de refúgio para expiação de crimes e pecados, de meditação sobre o sentido da vida e do sobrenatural. Por isso a travessia do deserto, tanto no sentido literal como no metafórico, dá origem, como na alquimia, a transformaçóes na personalidade daqueles que se aventuraram a caminhar nas suas veredas ou a habitar as suas grutas.

A primeira obra a atribuir ao sertão este estatutode lugar de penitência e reflexão foi precisamente uma das primeiras a construir o mito do sertão: OErmitäo de Muquém de Bernardo Guimarães. A sua personagem principal, Gonçalo, depois de uma vida agitada de amores violentos e de crueldades, retira-se para o sertão-deserto e ali leva uma vida de rigorosa penitência, purificando-se dos seus pecados. Conta o narrador:

"Apenas edificada a capelinha (da Senhora da Abadia), começou logo a afluência dos devotos que vinham fazer penitência, oferecer à Santa suas esmolas, e igualmente beijar o hábito do piedoso ermitāo que aí passou o resto dos seus dias zelando o santuário da Virgem e aí morreu venerado como um santo. É assim que dos grandes pecadores fazem-se os grandessantos, comoda imundície epodridāobrotamporvezes as mais lindas e viçosas plantas" (19).

Nesse lugar retirado do santuário da Senhora da Abadia, multidōes de romeiros iriam também, longe do bulício dos meios urbanos, fazer a conversão de suas vidas.

Depois de Bernardo Guimarães outros autores se ocuparam do sertão-deserto, lugar de meditação e penitência, salientandose, entre outros, José Lins do Rego, Guimarães Rosa e Ariano Suassuna.

Para José Lins, paira sobre o sertão algo de sagrado onde misteriosas maldições precisam ser exorcizadas para que chegue o reino da felicidade. Porque o sertão é reino a desencantar, como o mostrou o trágico episódio da Pedra Bonita. Falhou a tentativa messiânica e sebastianista do beato Sebastiāo, porque os pobres não conseguiram transformar-se em ricos e os negros em brancos dado que não aconteceu o desencanto da lagoa, masolugar continuou santo e misterioso, à espera de uma outra oportunidade.

Para Ariano Suassuna, o mistério do sertão, o seu clima psicológico e a presença

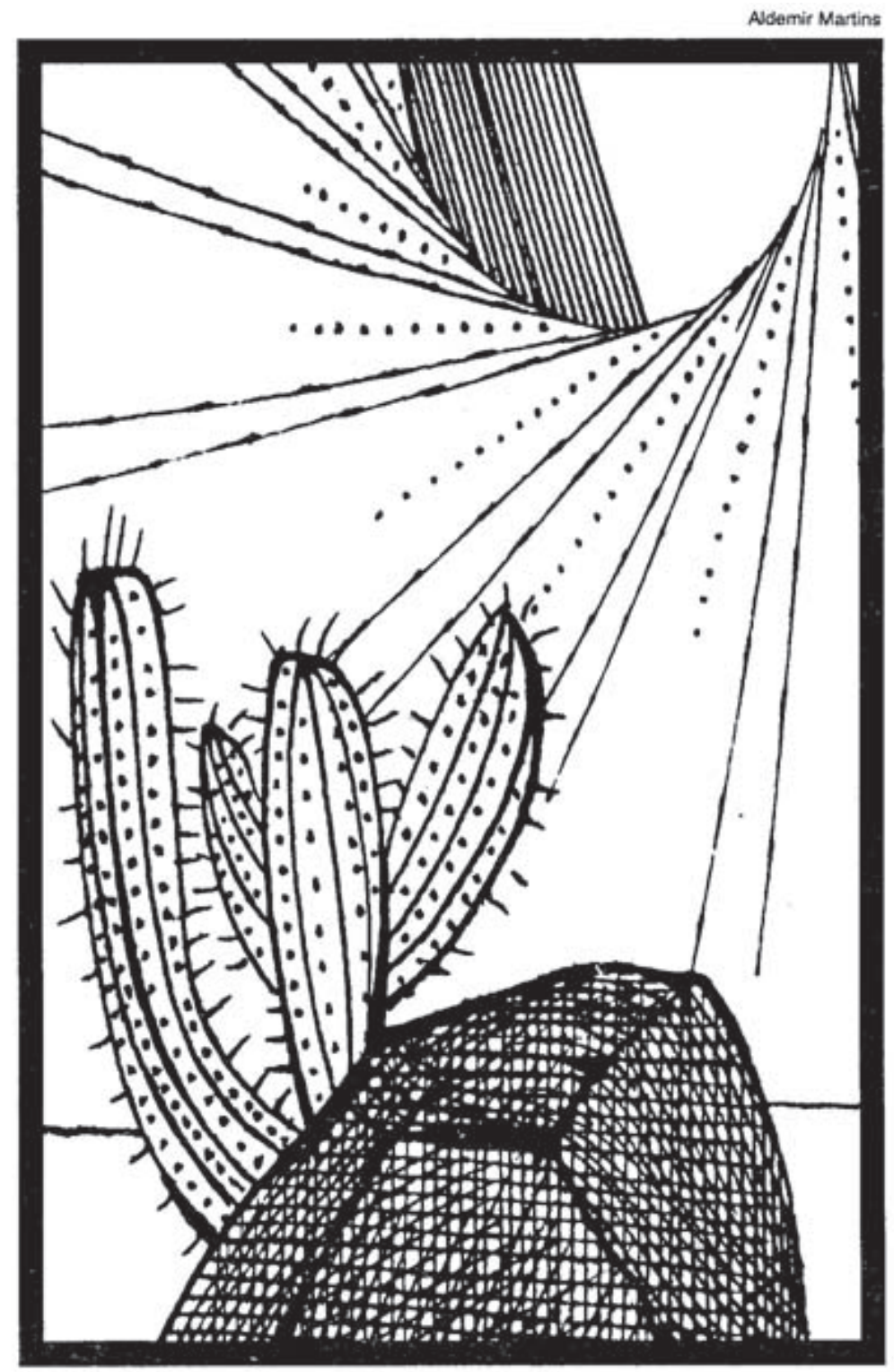

no imaginário coletivo residem também no fato de ele ser um reino a desencantar e decifrar. Reino simplesmente cultural e literárioou álibi para outra sabedoria e outras descobertas que o diálogo entre Quaderna e o Promotor da Justiça deixam antever?

Álibi que não deixa de insinuar que nesse reino a decifrar todas as fantasias são possíveis e nelas todos têm acesso à dignidade a que julgam ter direito, e que a vida prosaica de todos os dias lhes recusa, compensando-os da fome, da miséria, da mediocridade social e humana de suas vidas.

Com efeito, para Quaderna, a realidade nāo é a do sertão árido, pobre, de agitação política dos anos 30 , mas sim a das proezas num reinomítico, maravilhoso, onde as duas famosas pedras compridas e paralelas que se elevam da planura e sempre deslumbraram os matutos outra coisa não são senão
19 Bernardo Guimaróes, $O$ Ermitio de Muquén, SÄoPaylo, Martins, 1944, PP. 130-1. 
torres de castelo e fortaleza medieval. Para este novo D. Quixote, nessa fortaleza encantada habitara seubisavôD. JoãoFerreira. Castelo "encantado, do qual somente osangue nos podia lavar acabando de vez com a miséria do sertão e fazendo todos nós felizes, ricos, belos, poderosos, eternamente jovens e imortais". E não só Quaderna, em conformidade, reclama para si o estatuto de Rei e Imperador do novo Quinto Império, mas também as liberalidades honoríficas são vastas: os cangaceiros são cavaleiros medievais tal como os doze pares de França, os fazendeiros, reis, condes e barōes, e as filhas dos fazendeiros, princesas.

Pouco importa que outra seja a visão do Promotor da Justiça: Quaderna está a ser interrogadopor participação ativa em acontecimentos bem mais prosaicos, por ter presumivelmente participado na agitaçāo de 1935 a 1938, referentes a uma expedição sertaneja que, vinda dos sertōes da Paraíba, do Pernambuco e do Rio Grande do Norte, pretendia reeditar os feitos revolucionários da coluna Prestes em 1926. Além disso é acusadode se ter juntadoa Sinésio, ojovem do cavalo branco, com o objetivo de encontrarem o tesouro que financiaria a revolução comunista de Pernambuco, e de ter enviado a Sinésio um pacote de papéis com o roteiro do tesouro e vários documentos subversivosmandados porLuísCarlos Prestes, e ainda de ser o principal acusado no assassinato de seu padrinho, o fazendeiro D. Pedro Sebastiāo...

Tudo Quaderna nega, ou melhor, transfigura em acontecimentos do "Século do Reino", dando deles uma versão maravilhosa, porque, acima de tudo, ele é o "Decifrador" dos mistérios desse mesmo reino.

Mas aquele que mais profundamente penetrou nos mistérios do sertão-purgatório foi Guimarães Rosa, conseguindo fazer do sertão um tema universal, a ponto de, naturalmente, o aproximarmos do poema de Dante. Explorando veredas e trilhos, fez do Grande Sertāo: Veredas uma verdadeira epopéia moderna, na medida em que o romance é capaz de simbolizar, nos nossos tempos, o que o poema épico já conseguiu nos tempos passados.

Como no purgatório de Dante, duma forma especial, Rosa soube construir a arquitetura problemática da condição humana surpreendida nas suas sortidas voltas, compromissos e interrogaçōes da perigosa aventura do viver.
O sertão de Rosa participa, com o de José Lins e Suassuna, da atmosfera mágica do sobrenatural que paira em quase todas as obras sobre o sertão onde acontecem as epifanias mais estranhas. Internadosnosertão, endurecidos pelas suas asperezas e trabalhados pelos seus silêncios, Bentinho, Riobaldo e Quaderna confrontam-se com as forças sobrenaturais que lá habitam. A violência dos sentimentos experimentados e a perturbação causada por essas presenças misteriosas conduzem-nos ou a uma entrega nas mäos da divindade obscura, como se de uma rendição se tratasse, ou atiram-nos para atos meio alucinados cujo sentido não cessará depois de perscrutar.

Coube a Guimarães Rosa saber equacionar de maneira universalista o que Lins do Rego não foi capaz de desligar do localismo regionalista, $\mathrm{eSuassuna}$ nãoconseguiu emancipar de uma ambigüidade excessiva. E Rosa o fez principalmente recorrendo a um tópico cultural de grande audiência - o do pacto com o demônio -, dando, assim, ao itinerário do purgatório do homo viator, uma dramaticidade só alcançada por escritores e pensadores excepcionais.

O tópico do pacto aparece no Grande Sertão: Veredas, onde é mais expressivo, e n'A Pedra do Reino. Mas é em Guimarães Rosa, como conceito teológico e cultural próximo do mito de Fausto, que ele se afirma. No sertão de Suassuna, o pacto lá referido é mais implícito e sempre no contexto burlesco em que se movem o poeta integralista Samuel e os seus companheiros. O pacto de Samuel não deixa, contudo, de revelar-se curioso na sua ambigüidade, pois quer obter tanto a proteção do demônio como a dos anjos, servindo-se para isso de astúcias mais ou menos etimológicas e semânticas muito próprias doestilodo romance autodefinido como "de galhofa e safadeza".

O pacto de Riobaldo com "o demônio na rua, no meio do redemunho" das paixōes retoma a tradição do gênero, acrescentando-lhe um questionamento e um desfecho algo originais. O chefe de jagunços consideraque "Deusédefinitivamente", maspara conseguir o seu objetivo de vingar a morte de Joca Ramiro nāo hesita em se aliar ao diabo, dando-lhe a alma em troca.

Tudo se passa em ambiente tenso, misterioso, até porque algumas das personagens principais sảo ambivalentes entre o bem e o mal, são identificadas por nomes 
bíblicos e comportam-se como uma espécie de duplos das forças maléficas e das suas contrárias. Além disso apresentam-se como homólogas de personagens sagradas: Joca Ramiroécomparadoa Cristo, Riobaldo escolhe os seus jagunços como Cristo os apóstolos, e o traidor Hermógenes é quase sempre apresentado como Judas.

E tanto o pacto como a reflexão sobre ele seguem de perto a meditação de um eremita no deserto questionando-se sobre o seu grau de culpa. Riobaldo interroga-se, repetidamente: o diabo existe? Como é Deus? Será possível vender a alma?

A reflexão a que procede, decantada ao longo de todo o monólogo do romance, acaba por apontar uma conclusão: o pacto nảo é mais do que um momento mau do processo da escolha entre o bem e o mal, porque "pensando, não sou do demo e não sou de Deus", dado que entre os dois o homem é partilhado. Com efeito, é no seu interior que a verdadeira luta entre os dois se trava: Deus "existe - mas quase só por intermédio da acção das guerras”, e o diabo vige dentro do homem, os crespos do homem (...) solto, só por si, cidadão, é que não tem diabo nenhum".

Por isso o homem não é joguete de forças cegas mas antes senhor de se decidir por Deus e o bem, ou pelo demônio e pelo mal, ou melhor, as suas ações repartem-se nas duas direçōes. Essa a razão por que "viver é perigoso", pois a vida nāo é dada ao homem já feita como um destino fatal, mas tem de ser ele a construí-la segundo os seus desígnios.

Riobaldo sai da guerra, do sertão e do romance concluindo, como eremita que acabou a penitência $\mathrm{e}$ a jornada do deserto: "O diabo não há! Ésó o que eu digo, se for... Existeéohomem humano. Travessia"(20).

Diga-se, a propósito, que o ambiente de mistério, medo e expectativa é freqüentemente referido nas narrativas sobre o sertão. Nos contos e romances menores, como atmosfera típica da rusticidade em abundantes referências às assombraçōes -, nos mais felizes, para introduzir a manifestação epifânica e o que dela resultar. Comum a todas as obras, a presença do demônio, largamente servida pelo vocabulário tradicional e popular que nāo se limita a referi-lo mas também, em simultâneo, a exorcizá-lo insultando-o. Literariamente, é o demônio e nāo Deus que está em toda a parte.

Daía exuberância vocabular herdada em boa parte da tradição portuguesa e exímia na função de referir sem nomear, e que em Guimarães Rosa atinge o auge. Sem pretenções de inventário, recolhemos, nas obras sobre o sertāo, estas palavras como as mais expressivas: diabo, dianho, demo, Belzebu, Pero Botelho, sujo, bode, maligno, chifrudo, capeta, cảo, o que-diga, satanás, satanazim, capiroto, cujo, arrenegado, cramulhão, indivíduo, galhardo, pé-de-pato, o homem, tisnado, coxo, temba, azarape, coisa-ruim, mafarro, pé preto, canho, Duba-Dubá, rapaz, tristonho, não-sei-que-o-diga, o-que-nunca-se-ri, sem-gracejos...

Na Divina Comédia, a alegoria fundamental é a do conhecimento experimental de Deusenquantoobjetode amor, peloqual Dante se pôs a caminho saindo da "floresta obscura e selvagem" para viver uma experiência $\mathrm{e}$ adquirir um saber libertador. $\mathrm{O}$ aperfeiçoamento interior é a razão fundamental da sua viagem, e progredir na caminhada é progredir no caminho da sabedoria.

Embora de maneira não-teológica, até porque o tempoé o do quotidiano múltiplo e dividido próprio do romance como o assinalou Luckács e não o tempo unitário e trágico das epopéias, o itinerário dos viajantes do sertão é igualmente "obscuro e selvagem". Os viajantes aventuram-se ao perigo de viver interrogando-se sobre o modo de ultrapassar o transitório e fictício da vida, passam por diversos tipos de provas e provaçōes até chegarem a uma sabedoria e disposição de espírito que lhes permita alcançar a felicidade.

Durante a nova Divina Comédia deste percurso ficou claro que cada homem é o verdadeiro responsável pelo seu destino, $\mathrm{e}$ os fatos não são mais que momentos pontuaise não-definitivos de uma opção que só a globalidade das escolhas realizará plenamente.

Tendo tudo isto presente, e depois de verificar que o sertão ora é paraíso e locus amoenus, ora fornalha infernal e, permanentemente, espaço de purgatório onde se põe à prova o destino do homem, será que ainda se pode afirmar que a literatura do sertảo é de simples regionalismo? Ou antes, que o regionalismo é literatura menor, sobretudodepoisde nosterdadoobrascomo Grande Sertāo: Veredas ou A Pedra do Reino?

Mas essa é questão para responder em outra oportunidade.
20 Joh́o Guimarbes Rosa, Grande Sertilo: Veredes, $4^{*}$ ed. Rio, Josb Olimpio, 1965, Pp. 11,460 . 